\title{
The Geneva Association: Setting Standards for 25 Years
}

\author{
by Drs. Jan Holsboer*
}

The occasion of the 25th anniversary of the Geneva Association calls for a moment of reflection to look back on what has been accomplished over the years and to consider where we stand with regard to the future.

When the Geneva Association came into being in June 1973, there were 20 members from 8 European countries. Today there are 80 members from 22 countries.

In the past 25 years, the insurance industry has gone through some turbulent developments as a result of fundamental changes in Western economies. During this time, the Geneva Association has always been in the forefront of monitoring these changes and stimulating debate within the insurance industry and other economic sectors, as well as among governmental and scientific institutions.

In the first report to the assembly of members in 1974, the Association's first President, Mr. Raymond Barre, formulated its goals as follows:

- The Geneva Association has been founded to make an original contribution to the development of the insurance industry by means of objective studies which should examine the interdependence between the economy and the insurance industry;

- To this end, the Geneva Association will highlight the role of insurance in the economy and in modern society.

In the years that followed, it became apparent that these views were prescient for their time. Despite the high expectations of economic growth and stability which dominated Western thinking in the post-war period, the modern economy appeared to Group, NL. 
become vulnerable at the beginning of the 1970's. That vulnerability was shaped, among other things, by the shocks caused by the oil crisis. The very result of this economic uncertainty became one of the driving forces of the growing importance of insurance in the decades following the Geneva Association's founding.

The growing complexity of Western economies and the consequences of using technology of an ever increasing sophistication added to this vulnerability and, accordingly, to the growing importance of the insurance industry in a modern economy. In this way, the management of risk and vulnerability has become a fundamental strategic element of economic management. The Geneva Association has stimulated research in these areas, both on a micro level, where insurance meets the risk management problems of its clients, as well as on a macro level, in which the uncertainties of the global economic environment are addressed.

Many of the Geneva studies have been performed in the field of international economics, such as on trade barriers, the world monetary crisis and the consequences of the European monetary system. Much research has also - and is still - being forged on the consequences of the transition in the West from industrial economies to service economies. It has been noted by previous writers that the shift to a service economy in itself created a strong impetus to enhancing the image and position of the insurance industry: the services industry requires a judgement of future costs of utilisation based on probability models, thus touching on the typical concepts and expertise of the insurance industry. The notion of uncertainty, or even indetermination, has now been firmly established and integrated into the modern vision of economics, both in practice as well as on a theoretical level. The Geneva Association has played a prominent role in promoting this paradigm of dynamic management.

Another important field of research with a macro focus has been the interface of insurance and social security. The Association's research program on social security, savings, and life insurance has been conducted since the mid-70's, a time when social security was still regarded as a domain entirely separate from private insurance. The emergence of private insurance as a complement --or even substitute- of social security schemes has been strongly promoted by several important publications and other Geneva activities. It has now become an accepted part of economic thinking.

The Four Pillars concept, first formulated in 1985, also served to strongly influence public thinking. An example is the German Pension Reform Act which incorporates the main lines of thought of the Four Pillars concept. The study of demographic developments in their relation to issues such as labor participation, unemployment and part-time work, as advocated by Geneva research, will continue to be high on the political agenda in the West in the years ahead. It is fair to say that the Geneva Association has made valuable contributions to all these issues.

Research on a micro level has focused on the identification of risks in the various economic sectors. Much study has been directed towards the risks relating to industrial developments and technology, for example in the chemical and related industries. Modern technology has rendered the problem of vulnerability very acute. Although the frequency of risk of malfunction has been declining, the exposures are reaching higher and higher levels. Not only are industrial systems posing questions about vulnerability. There has also 
been a growing concern over environmental consequences and potential climate changes. Another such field of growing importance has been has been liability risk.

All these developments have pointed towards the necessity of studying the relationship between risks and insurance and applying it for the management of today's economic reality. The fundamental change in basic attitudes about the problems of risk and insurance is underlined by the emergence of the field of risk management, as witnessed by the studies of the Geneva Association.

Risks are no longer just an act of God: they can be managed!

Another striking element that comes forth from the Geneva publications is the constant emergence of new risk categories in relation to technological development. There have been studies on space projects, biotechnology, gene technology, to name just a few. The tremendous pace at which new developments are affecting our industry is underscored by looking back at an early study, published in 1979, on risks and indirect losses due to the use of computerised systems. At that time, computers were still rare in a regular office. Today, distribution by the Internet is likely to become a risk management field of its own. Similarly, a completely new class of risks emerged in relation to the millenium problem. In short: the types and numbers of risks in modern society seem to be developing continuously.

This brings me to the notion of insurability, which is an issue of growing significance. In recent years, several special issues of the Geneva papers have been devoted solely to this theme and it has also been selected as the number one research priority on the agenda of the Geneva Association. Insurability is a key issue in determining where private activity ends and where public intervention begins, and vice-versa. The Geneva Association has stressed the importance for economists and politicians to understand and define its notion as a key factor for the success of economic policy.

From all of these developments, one conclusion stands out clearly: that insurance and risk management have become major strategic economic issues in today's world.

Quoting earlier contributions:

- Both are an essential complement to all social security and savings policies;

- They are an essential complement to any health policy;

- They provide key professional methods for the assessment and management of technological, industrial and environmental risks;

- Entrepreneurial risk depends on properly understanding and controlling pure risk.

With regard to the future of the insurance industry, many challenging issues remain to be tackled. To this end, clear priorities for research activities have been defined and endorsed at recent general assemblies.

The subject of insurability has already been mentioned as the number one priority. It has been suggested to incorporate this issue as a discussion theme in all seminars and publications organised by the Geneva Association. It is vital to deliver the message in society that all types of risk must first be defined in terms of their insurability and that reaching a reasonable level of insurability is a prerequisite for private activity. 
The second priority concerns the present and future development of health systems, in particular in relation to the ageing process and the sharply rising cost of medicine.

In the last year, efforts have been made to identify strategic points of references and issues in which the Geneva could play its typically innovative and effective role.

Complementary to the above is a third priority, which is to continue studying demographic trends and the limits to social security (Four Pillars program). Priority number four is the evolution of legal systems, which was already taken up at the seminar in Hamburg, and will be further developed in collaboration with the European Association for Law and Economics.

In order to realize the goals set by these priorities, it is desirable to conduct research activities on a more coordinated level, stimulating closer interaction and cooperation between universities and other public institutions, professional research institutes and research departments in the insurance and financial industry itself. Personal contacts and networking between research fellows and experts in the industry will have to be intensified. The Geneva Association could play a key role in offering a platform to bring these parties together.

The original reasons for founding the Geneva Association are still valid today. And nowadays it has only become more clear how pioneering the founding fathers were in their views. Throughout its existence the Geneva Association has embarked on an increasing number of activities and networks, always in search of reaching new frontiers.

One new and fundamental task that has been added to the mission of the Geneva Association is the development of the Association as an international Forum for its members and the insurance industry as a whole. This will be a main activity in the coming years.

The forum concept serves the aim to provide Chief Executive Officers of the major insurance companies with an opportunity to exchange ideas and discuss key strategic issues of current interest. This is a formula for which members have expressed great interest and which with the Association's membership is unique to the insurance industry.

At the last General Assembly in Brussels, the contours of such development were discussed, including the idea of organising future discussions following the model of the Institute International d'Etudes Bancaires. According to this approach, members prepare thorough papers on issues of current interest, which are written and distributed in advance, allowing efficient discussions to take place. The choice of subjects and organisation of discussion panels are co-ordinated by of one of the members.

With regard to the future discussion topics for the Geneva Association, it would be highly recommended to include aspects of asset management and banking as well. With the blurring borders between traditionally distinct categories of financial services, the creation of an increasing number of financial conglomerates and the growing demand for a comprehensive range of financial services, the activities of insurers, bankers and asset managers are becoming more interrelated. Furthermore, the topics should, more than ever before, be regarded in a worldwide context. The globalisation of the financial markets and the ongoing revolution of information technology and communications has made our 
world a small place. The recent financial crisis in Asia has demonstrated that regional developments also have an impact on the financial markets in other parts of the world. The creation of the Economic and Monetary Union and the future EU and NATO membership of several countries in Central and Eastern Europe will certainly contribute to further integration of the financial markets.

I also believe that special attention should be paid to new forms of distribution of financial products and services. Distribution has always been a crucial factor in the insurance industry, but I am firmly convinced that effective distribution will be the principal denominator for success in the financial services industry in the 21st century. While direct marketing is becoming an important form of distribution for standardized personal lines products, there will definitely be a demand for expert advice from professional intermediaries who are able to offer tailor-made solutions to the clients. The number and compexity of financial services are rapidly increasing and this will make heavy demands on the professionalism of financial service providers and their intermediaries. Attention must also be paid to the growing competition by new providers from outside the financial sector and to new distribution options created by the Internet and other electronic media.

In the past 25 years, the Geneva Association has had to battle with a structural mismatch between the number of ideas that were generated and the human and financial resources that were available to realize those ideas. I would like to say that I am greatly impressed by the results the Geneva Association has achieved with these resources. We have to be realistic that our resources are too limited to adequately address all the future challenges just outlined. However, I believe that the Geneva Association can play an extremely valuable coordinating role in mustering research capabilities in member companies and external scientific organizations for common purposes. A sharper focus on research priorities and closer links with universities and other institutions will enable the Geneva Association to enhance its role as a front-runner in our industry and to connect research more closely to the practical application of current strategic management issues.

There are still many challenges that lie ahead in our industry, in a world that is changing at breathtaking pace. The Geneva Association has already played, and will continue to play a more vital role in facilitating its members and the insurance industry as a whole in facing these challenges.

In conclusion, a debt of gratitude and thanks is due to all those who have contributed to the work of the Geneva Association, including the founding fathers of the Association, its members, researches, and support staff. A special word of appreciation should be expressed here to Orio Giarini who has been the energetic, stimulating and a dedicated secretary General of our Association for 25 years. The vision and innovative spirit of the Geneva Association have helped to redefine the role of the insurance industry in a rapidly changing world. 